\title{
Cation effects on ammonia volatilization loss from urea applied to a tropical soil
}

\begin{abstract}
Ammonia volatilization loss from surface-applied urea is an important problem even in tropical soils. The presence of cations at urea microsites during urea hydrolysis can reduce ammonia volatilization loss. Laboratory, and field experiments were carried out to study the effect of cations on ammonia volatilization loss from urea applied to a tropical soil. In the laboratory study urea treated with $\mathrm{Ca} 2+, \mathrm{Mg} 2+$ or $\mathrm{K}+$ at the rate $0,0.25,0.5,1.0$ and 2.0 cation/N (chemical equivalent ratio) were applied on the surface of the Bungor top soil (Typic Paleudult). Ammonia volatilization loss was determined daily for a duration of one week by using the force draft technique. In the field study ammonia volatilization loss was determined by using $15 \mathrm{~N}$ recovery technique. In this experiment $15 \mathrm{~N}$ labelled urea treated with $\mathrm{Ca} 2+, \mathrm{Mg} 2+$ or $\mathrm{K}+$ at the rate of $0,0.5$ and 1.0 cation/ $\mathrm{N}$ (chemical equivalent ratio) were surface-applied in micro plots. Ammonia volatilization loss was determined at the end of one week and two weeks. In the laboratory study treatments of urea with $\mathrm{Ca} 2+, \mathrm{Mg} 2+$ or $\mathrm{K}+$ were effective in reducing ammonia volatilization loss. The effectiveness improved with increasing the rate of cations. At the highest rate of the cation added (2.0) the losses were reduced from $36.9 \%$ to less than $13.1 \%$. In the field experiment $\mathrm{Ca} 2+, \mathrm{Mg} 2+$ and $\mathrm{K}+$ effectively reduced ammonia volatilization loss. The ammonia volatilization loss was reduced from $27.7 \%$ to less than $15.2 \%$ in one week. Subsequently more fertilizer N was recovered in the treated soils. Thus we conclude that surface application of urea with $\mathrm{Ca} 2+, \mathrm{Mg} 2+$ or $\mathrm{K}+$ reduced ammonia volatilization.
\end{abstract}

Keyword: Ammonia; N losses; Urea; Volatilization 